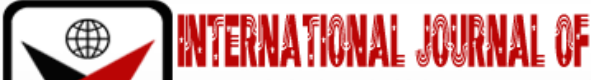

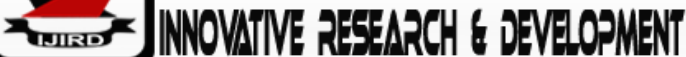

ISSN 2278 - 0211 (Online)

\section{Assessment of Covid-19 Vaccine Hesitancy among Residents of Plateau State, Nigeria}

Okoh Elizabeth
Lecturer, Department of Community Medicine,
University of Jos, Nigeria
Gwomson Dauda
Resident Doctor, Departmentof Community Medicine,
Jos University Teaching Hospital, Nigeria
Makput Bala
Resident Doctor, Department of Community Medicine
Jos University Teaching Hospital, Nigeria
Dasat Grace
Resident Doctor, Department of Community Medicine,
Jos University Teaching Hospital, Nigeria
Chirdan Oluwabunmi
Professor, Department of Community Medicine,
Jos University Teaching Hospital, Nigeria

\section{Abstract:}

Background: The refusal or delay in acceptance of proven effective vaccines including the newly introduced COVID-19 vaccines, has the potential to adversely affect the control of vaccine preventable diseases. This study was conducted to determine the level and predictors of hesitancy against COVID-19 vaccine that is yet to be made available to the general public in Plateau State among selected residents.

Methodology: A scenario-based, cross-sectional study was conducted among 300 selected adults before the availability of COVID-19 vaccine using e-questionnaires in which scenarios for COVID-19 vaccination were created. IBM SPSS version 23 was used for data analysis and logistic regression for identification of predictors. A P-value of $\leq 0.05$ was considered statistically significant.

Results: The mean age of the respondents was $35.5 \pm 9.5$ years and $66.7 \%$ were males. Over half (55.3\%) of respondents had poor knowledge of vaccines. The prevalence of vaccine hesitancy was 46\% with fear of side effects accounting for the highest reason for the hesitancy (17.2\%), followed by doubts about vaccine efficacy (15.5\%) and doubts about the policies guiding vaccination (12.4\%). COVID-19 self-risk perception (AOR= 2.4; $95 \%$ CI $=1.161-$ 4.980) and previous history of vaccination against any disease (AOR=3.609; 95\% CI =1.000 - 13.023) were found to be significant predictors of vaccine hesitancy.

Conclusion: This study has demonstrated that almost half of respondents were hesitant to take COVID-19 vaccine. There is need to embark on health education to members of the general public on importance of COVID 19 vaccination.

Keywords: COVID-19, vaccine, hesitancy, plateau state

\section{Introduction}

Vaccination has been recognized as one of the most successful public health measures of the past century [1]. Vaccination alone prevents the loss of US\$ 375 billion to the global economy every month[2]. Despite this, many more people perceive it as unsafe and unnecessary and this lack of confidence in vaccines has been noted as one of the major threats to the success of vaccination programs. Vaccine hesitancy is believed to be responsible for the increasing risk of vaccine-preventable disease outbreaks and epidemics [1]. Vaccine hesitancy is a term used to describe the range of feelings people have about vaccine concerns. It refers to delay in acceptance or refusal to receive vaccines despite the availability of such vaccines [3]. Individuals may hesitate or choose not to be vaccinated for various reasons which may range from lack of confidence (do not trust a vaccine or provider), complacency (do not perceive a need for a vaccine or do not value the vaccine), and inconvenience (access). Other reasons for vaccine hesitancy include vaccine safety concerns and fear of side effects. Factors like lack of awareness/knowledge of vaccination, religion, culture, gender and other socioeconomic conditions may also contribute to hesitancy [4]. 
Vaccine hesitancy is complex and context specific. It varies across time, place and person. It can be described on a continuum ranging from those who accept all vaccines without any doubt to those who reject all without any doubt. The large, heterogeneous group of individuals between these two extremes exhibits varying degrees of hesitancy. Some may refuse or delay some vaccines and accept others, while some individuals may refuse all vaccines[5]. A little above $90 \%$ of WHO countries have been reporting one form of vaccine hesitancy globally over the years. During the period of $2014-$ 2017, the African Region showed some increased response rate to vaccination compared to other regions[4].

Since the onset of COVID-19 pandemictill the second week of March 2021, up to 120 million cases with over 2.6 million deaths had been reported worldwide, while more than 160 thousand cases and over 2000 deaths had been reported in Nigeria [6].This global pandemic has caused tremendous problems to individual, families, nations and the world at large. Apart from the millions of lives that have been lost, economies have been disrupted and countries, including Nigeria have been thrown into recession. Several efforts have been made to control the pandemic among which is the development of vaccines against the disease. Several COVID 19 vaccines have been developed by scientists working tirelessly across the world. There are four broad classes of vaccines currently being developed or in use against COVID-19 and they include: Inactivated or weakened virus vaccines (uses the weakened form of the virus), protein-based vaccines (uses protein fragments or protein shells to mimic the virus), viral vector vaccines (uses a genetically-engineered virus) and the RNA and DNA vaccines (uses genetically engineered RNA or DNA)[7].Over 200 vaccine candidates of these categories are in development, of which more than 60 are undergoing clinical trials[8]. The WHO has givenEmergency Use Authorization (EUA) to four COVID-19 vaccines which include the Pfizer BioNTech Vaccine, Moderna Vaccine, Astrazeneca Vaccine and Janssen Vaccine[9, 10].Equitable distribution targeting health workers and the most-at-risk population will go a long way in mitigating the public health and economic impact of the pandemic. The WHO is supporting this process in collaboration with other stakeholders. COVAX, a global initiative launched by the World Health Organization, the European Commission, and France as a global response strategy to ensure equitable access to COVID 19 vaccine in 190 countries across the globe [11].

In the past, many rumours and misconceptions have negatively impacted on the success and effectiveness of vaccination programs on the African continent. One of such examples is the polio vaccine boycott that occurred in Northern Nigeria between 2003 and 2004 which was fuelled by distrust and fallacies concerning the vaccine. This resulted in a five-fold increase in polio incidence observed in the country between 2002 and 2006, and subsequently a spread of the outbreak to other continents. Misconceptions and myths among community members also contributed to the failure of a mass deworming programme in Ghana. These examples show how hesitancy to vaccination and other interventions can pose significant risks to individual and global health $[12,13]$.

Despite the huge global and national efforts made to achieve successful roll out of the approved and prospective COVID-19 vaccines, a major hindrance can be refusal or delay to get vaccinated by the populace. Some basic misconceptions about COVID-19 vaccines have been seen to be in circulation most especially on social media during the peak of the disease, some of which include concerns about the safety of the vaccines if made available given the rapid development and testing process; underlying suspicion about vaccines among segments of the population; mistrust of the government's pandemic response, lack of trust in the medical community. Concerns have also arisen eluding to the fact that COVID-19 pandemic is part of a strategy conceived by global elites such as Bill Gates, to roll out vaccinations with tracking chips that would later be activated by $5 \mathrm{G}$, the technology used by cellular networks $[14,15]$.

With Plateau State being among the worst hit states in Nigeria, third only to Lagos and the FCT, and having reported over 9,000 cases and nearly 60 deaths as at $3^{\text {rd }}$ week of March 2021[16], there is need to intensify control efforts including vaccination against the disease. This study was aimed at assessing the level of hesitancy that might be encountered should COVID-19 vaccines be made available and to determine the predictors of this hesitancy. This will avail the opportunity for public health practitioners, policy makers and other stakeholders to anticipate and plan on measures that will be used to address resistance to approved vaccines against COVID-19.

\section{Methodology}

\subsection{Study Area}

This study was carried out in Plateau state, North Central Nigeria with an estimated land area of approximately 26,890 sq.km lying between latitude $80^{\circ} 22^{\prime}$ and $100^{\circ} 20^{\prime}$ North and longitude $80^{\circ} 32^{\prime}$ and $100^{\circ} 38^{\prime}$ East. Plateau is divided three senatorial zones and 17 Local Government Areas (LGAs) and has an estimated population of over 4 million[17]. The official languages spoken include English and Hausa. The adult literacy rate in English was 59\% in 2010.

Study design and population. A scenario-based descriptive cross-sectional study was carried out using electronic means of data collection among adults (18 years and above) who are residents of Plateau State, Nigeria. Data was collected at a time when COVID-19 vaccines were not yet available hence, scenarios for COVID-19 vaccinations were created. An adult who is residents in Plateau State, has a registered mobile number and has access to internet services was included in the study, while any adult that was neither literate in English nor Hausa was exempted from the study.

Sample size

The minimum sample size (n), for the study was determined using the Cochrane formula.

$\mathrm{N}=\mathrm{z}^{2 *} \mathrm{p}(1-\mathrm{p}) / \mathrm{e}^{2}$ (Where $\mathrm{n}=$ minimum sample size; $\mathrm{z}=95 \%$ standard normal deviate of $1.96 ; \mathrm{p}=$ vaccine acceptance rate of $82 \%$ in South Africa[18]; and e = desired margin of error at 0.05 )

$\mathrm{N}=227$ up to 300.

Putting into consideration a non-response rate of $10 \%$, the sample size was calculated was 250 . This was rounded 


\subsection{Sampling Technique}

Simple random sampling technique was used to select the sample population. A list of eligible adults with active phone numbers in Plateau State served as the sampling frame. The required sample was selected using the computer generated simple random sampling technique. On selection of a participant that did not meet the selection criteria the next eligible person on the list was selected.

Data collection instrument and process

Data was collected using an e-questionnaire developed in Microsoft forms. The questionnaires captured information on socio-demographic characteristics of the respondents and receptiveness/hesitancy to COVID-19 vaccine.

Selected participants were contacted via telephone calls and informed of the study objectives, voluntariness and confidentiality of the study was ensured. They were informed about a link that would be sent to their phones through SMS, WhatsApp, Email or any other preferred platform. The link to the survey contained a brief introduction and objectives of the study, an informed consent section and the questionnaire section.

\subsection{Data Analysis}

Vaccine hesitancy was assessed by creating scenarios of COVID-19 vaccine availability and asking whether respondent will be willing to accept vaccination when eventually it is made available. If the respondent answered negative (No) or not sure to the question, he/she was taken to be vaccine hesitant.Knowledge of vaccination was assessed by scoring of responses and grading them as good ( $\geq 80 \%$ of total scores), fair ( $\geq 60 \%$ to $<80 \%)$ and poor $(<60 \%)$.

Responses were downloaded into the Microsoft excel spreadsheet and exported to IBM Statistical Package for the Social Sciences (SPSS) version 23 for analysis. Data were presented in figures, tables and charts. Chi-square test was then used to determine factors that had significant association with vaccine hesitancy while logistic regression was used to identify independent predictors. A p-value of $\leq 0.05$ was regarded as statistically significant.

\subsection{Ethical Considerations}

Permission for the study was obtained from the State Ministry of Health before commencement of data collection. Ethical clearance was obtained from the Plateau State Ministry of Health Ethical Committee. Confidentiality was assured and informed consent was obtained from the respondents.

\section{Results}

A total of 300 participants participated in the study. The mean age of the respondents was $35.5 \pm 9.5$ years with the highest proportion of respondents aged between 35 - 39 years (25.3\%). There were more males 200 (66.7\%) than females and more respondents 137 (45.7\%) were from the northern senatorial zone. More respondents were married 173 $(57.7 \%)$ and had completed tertiary education 132 (44.0\%).

\begin{tabular}{|c|c|c|}
\hline Characteristics & Frequency $(n=300)$ & Percentage (\%) \\
\hline Age group (years) & & \\
\hline $18-24$ & 31 & 10.3 \\
\hline $25-29$ & 54 & 18.0 \\
\hline $30-34$ & 52 & 17.3 \\
\hline $35-39$ & 76 & 25.3 \\
\hline $40-44$ & 40 & 13.3 \\
\hline $45-49$ & 17 & 5.7 \\
\hline Mean \pm SD $(35.5 \pm 9.5$ years $)$ & & \\
\hline Sex & & \\
\hline Male & 200 & 66.7 \\
\hline Female & 100 & 33.3 \\
\hline Religion & & \\
\hline Christianity & 245 & 81.7 \\
\hline Islam & 55 & 18.3 \\
\hline Ethnicity & & \\
\hline Plateau Indigenous & 250 & 83.3 \\
\hline Non-Plateau Indigenous & 50 & 16.7 \\
\hline Senatorial district & & \\
\hline Northern & 137 & 45.7 \\
\hline Central & 92 & 30.7 \\
\hline Southern & 71 & 23.7 \\
\hline Residential locality & & \\
\hline Rural & 195 & 65.0 \\
\hline Urban & 105 & 35.0 \\
\hline Marital Status & & \\
\hline Single & 109 & 36.3 \\
\hline Married & 173 & 57.7 \\
\hline Separated & 3 & 1.0 \\
\hline Divorced & 2 & 0.6 \\
\hline Widowed & 13 & 4.3 \\
\hline
\end{tabular}




\begin{tabular}{|c|c|c|}
\hline Characteristics & Frequency $(n=300)$ & Percentage (\%) \\
\hline Educational status & 12 & 4.0 \\
\hline None & 12 & 4.0 \\
\hline Qur'anic & 13 & 4.3 \\
\hline Incomplete primary & 18 & 6.0 \\
\hline Complete & 25 & 8.3 \\
\hline Incomplete secondary & 42 & 14.0 \\
\hline Complete secondary & 36 & 12.0 \\
\hline Incomplete tertiary & 132 & 44.0 \\
\hline $\begin{array}{c}\text { Complete tertiary } \\
\text { Other }\end{array}$ & 10 & 3.3 \\
\hline \multicolumn{3}{|l|}{ Employment status } \\
\hline Civil servant & 69 & 23.0 \\
\hline Business man/woman & 81 & 27.0 \\
\hline Student & 30 & 10.0 \\
\hline Farmer & 26 & 8.7 \\
\hline Health worker & 16 & 5.3 \\
\hline NGO & 20 & 6.7 \\
\hline Housewife & 14 & 4.7 \\
\hline Unemployed & 44 & 14.7 \\
\hline \multicolumn{3}{|l|}{ Monthly income (Naira) } \\
\hline$\leq 30,000$ (Minimum wage) & 185 & 61.7 \\
\hline$>30,000$ and above & 115 & 38.3 \\
\hline Mean income & & \\
\hline \multicolumn{3}{|l|}{ Has a child/children } \\
\hline Yes & 186 & 62.0 \\
\hline No & 114 & 38.0 \\
\hline \multicolumn{3}{|l|}{ Number of children } \\
\hline$\leq 4$ & 135 & 72.6 \\
\hline$>4$ & 51 & 27.4 \\
\hline
\end{tabular}

Table 1: SociodemographicCharacteristics of Respondents

SD=Standard Deviation. ${ }^{*}=$ Hausa, Igbo, Yoruba, Tiv, Idoma, Esan, Kilba,

Kagoro $^{* *}=$ Business/Trade Schools, Adult Education, Home School

Table 2 showed that just a quarter 76 (25.3\%) considered themselves to be at high risk of getting infected with COVID-19. Furthermore, 144 (48.0\%) were aware of at least someone that had died of COVID-19.

\begin{tabular}{|c|c|c|}
\hline Variable & $\begin{array}{c}\text { Frequency } \\
\text { (n=300) }\end{array}$ & $\begin{array}{c}\text { Percentage } \\
\text { (\%) }\end{array}$ \\
\hline Self-risk perception of COVID 19 & & \\
High perception of risk & 76 & 26.3 \\
Some perception of risk & 144 & 48.0 \\
No perception of risk & 80 & 26.7 \\
\hline Awareness of any mortality associated & & \\
with COVID 19 & 114 & 38.0 \\
Yes & 136 & 62.0 \\
No & \\
\hline
\end{tabular}

Table 2: Self-risk Perception of COVID-19

Table 3 showed that although most respondents $(277,92.3 \%)$ had been previously vaccinated and 175 of them had vaccinated their children in the past mainly with the routine childhood vaccinations, only few respondents (34, $11.3 \%$ ) demonstrated good knowledge of the importance of vaccines. 


\begin{tabular}{|c|c|c|}
\hline Variable & Frequency & Percentage (\%) \\
\hline $\begin{array}{l}\text { Knowledge of vaccine importance }(\mathrm{n}=300) \\
\text { Good } \\
\text { Fair } \\
\text { Poor }\end{array}$ & $\begin{array}{c}34 \\
100 \\
166\end{array}$ & $\begin{array}{l}11.3 \\
33.3 \\
55.3\end{array}$ \\
\hline $\begin{array}{c}\text { Previous Vaccination History }(\mathrm{n}=300) \\
\text { Yes } \\
\text { No }\end{array}$ & $\begin{array}{c}277 \\
23\end{array}$ & $\begin{array}{c}92.3 \\
7.7\end{array}$ \\
\hline $\begin{array}{c}\text { Type of vaccine ever used }(\mathrm{n}=277) \\
\text { Routine Childhood vaccines only } \\
\text { Other types only* } \\
\text { Both }\end{array}$ & $\begin{array}{c}131 \\
64 \\
82\end{array}$ & $\begin{array}{l}47.3 \\
23.1 \\
29.6\end{array}$ \\
\hline $\begin{array}{l}\text { History of vaccination of children }(n=186) \\
\text { Yes } \\
\text { No }\end{array}$ & $\begin{array}{c}175 \\
11\end{array}$ & $\begin{array}{c}94.1 \\
5.9\end{array}$ \\
\hline $\begin{array}{c}\text { Type of vaccine children received }(\mathrm{n}=175) \\
\text { Routine Childhood vaccines only } \\
\text { Other types only* } \\
\text { Both }\end{array}$ & $\begin{array}{c}132 \\
6 \\
38\end{array}$ & $\begin{array}{c}75.4 \\
2.9 \\
21.7\end{array}$ \\
\hline
\end{tabular}

Table 3: Knowledge of Vaccines and Vaccination Status of Respondents ${ }^{*}=$ Yellow Fever, Hepatitis B\&C, Tetanus Toxoid, HPV

Almost half $(138,46.0 \%)$ of the respondents had vaccine hesitancy as depicted in figure 1.

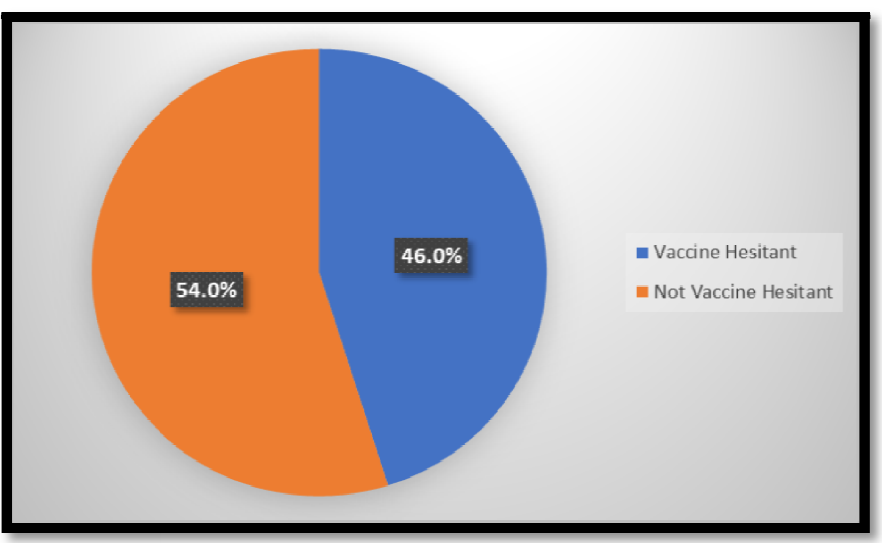

Figure 1:Prevalence of COVID-19 Vaccine Hesitancy among Respondents

The main reasons for the hesitancy to COVID-19 vaccines as shown in figure 2 include: concerns about side effect (17.2\%), doubting the efficiency of the vaccine (15.5\%) and not being sure of the policies guiding vaccination (12.4\%).

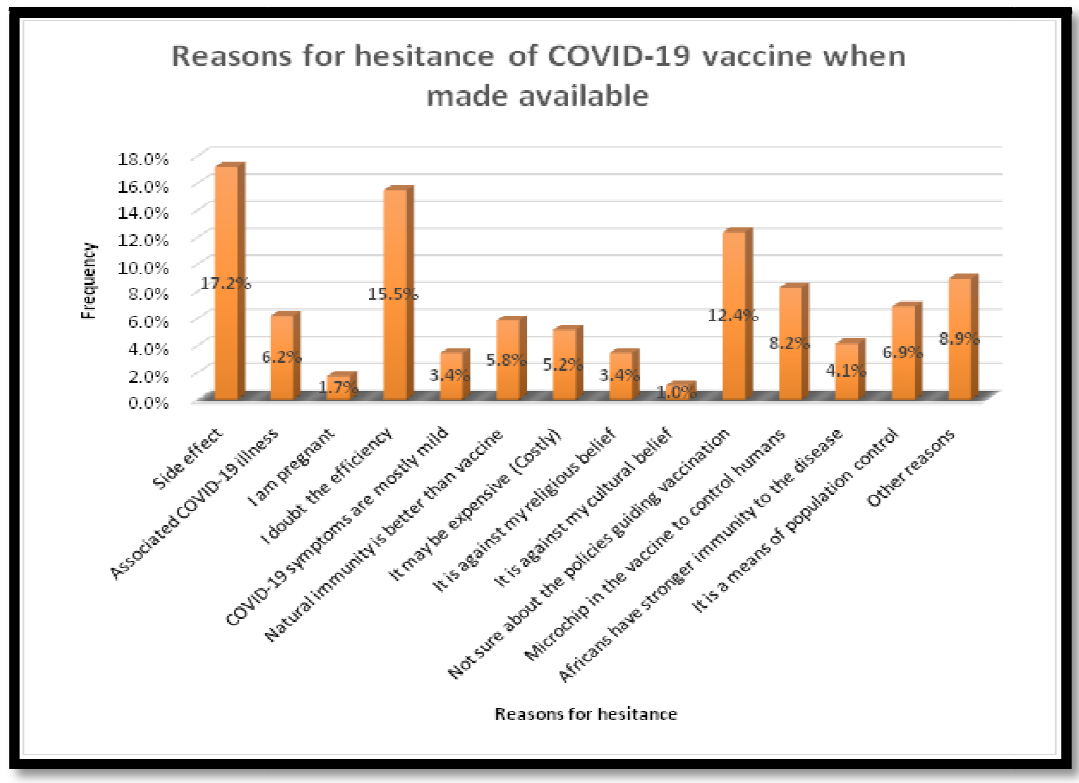

Figure 2: Reasons for Hesitance of COVID-19 Vaccine When Made Available 
Other reasons given include: The vaccine has not passed clinical trial; Lack of trust of the vaccine; The authorities do not speak with one voice concerning covid-19; People in government will use it to make money; It is a man-made disease, hence it is biological weapon; There is a lot of controversy surrounding vaccination; I do not believe in the existence of COVID-19.

The level of education of respondents $\left(\chi^{2}=4.023 ; \mathrm{P}=0.045\right)$, knowledge of vaccine importance $\left(\chi^{2}=16.40 ; \mathrm{P}=\right.$ $<0.001)$, self-risk perception of COVID $\left(\chi^{2}=22.015 ; \mathrm{P}<0.001\right)$, awareness of any COVID-19 associated mortality $\left(\chi^{2}=\right.$ 10.288; $\mathrm{P}<0.001)$, previously history of vaccination for respondent $\left(\chi^{2}=5.569 ; \mathrm{P}=0.018\right)$ and child's previous vaccination $\left(\chi^{2}=9.078 ; P=0.003\right)$ were all found to be statistically significantly associated with vaccine hesitancy on bivariate analysis (Table 4).

\begin{tabular}{|c|c|c|c|c|c|c|}
\hline & $\begin{array}{l}\text { Vacc } \\
\text { Hesi }\end{array}$ & & $\begin{array}{r}\text { Not V } \\
\text { Hes }\end{array}$ & & & \\
\hline Factors & $\begin{array}{c}\text { Freq } \\
N=300\end{array}$ & $\%$ & $\begin{array}{c}\text { Freq } \\
N=300\end{array}$ & $\%$ & $\chi^{2}$ & p-value \\
\hline $\begin{array}{l}\text { Senatorial district } \\
\text { Northern zone } \\
\text { Central zone } \\
\text { Southern zone }\end{array}$ & $\begin{array}{l}62 \\
46 \\
30\end{array}$ & $\begin{array}{l}45.3 \\
46.0 \\
42.3\end{array}$ & $\begin{array}{l}75 \\
46 \\
41\end{array}$ & $\begin{array}{l}54.7 \\
46.0 \\
57.7\end{array}$ & 1.02 & 0.599 \\
\hline $\begin{array}{l}\text { Marital status } \\
\text { Never married } \\
\text { Ever married } \\
\end{array}$ & $\begin{array}{l}52 \\
86 \\
\end{array}$ & $\begin{array}{l}47.7 \\
45.9 \\
\end{array}$ & $\begin{array}{c}57 \\
105 \\
\end{array}$ & $\begin{array}{l}52.3 \\
55.0 \\
\end{array}$ & 0.20 & 0.718 \\
\hline $\begin{array}{c}\text { Level of education } \\
\text { Pre-secondary } \\
\text { Secondary and above } \\
\end{array}$ & $\begin{array}{c}32 \\
106 \\
\end{array}$ & $\begin{array}{l}58.2 \\
43.3 \\
\end{array}$ & $\begin{array}{c}23 \\
139 \\
\end{array}$ & $\begin{array}{l}41.8 \\
56.7 \\
\end{array}$ & 4.02 & $0.045^{*}$ \\
\hline $\begin{array}{c}\text { Employment status } \\
\text { Employed } \\
\text { Unemployed } \\
\end{array}$ & $\begin{array}{l}82 \\
56 \\
\end{array}$ & $\begin{array}{l}44.1 \\
49.1 \\
\end{array}$ & $\begin{array}{c}104 \\
58 \\
\end{array}$ & $\begin{array}{l}55.9 \\
50.9 \\
\end{array}$ & 0.72 & 0.396 \\
\hline $\begin{array}{l}\text { Profession } \\
\text { Health worker } \\
\text { Others }\end{array}$ & $\begin{array}{c}5 \\
133\end{array}$ & $\begin{array}{l}31.3 \\
46.8\end{array}$ & $\begin{array}{c}11 \\
151\end{array}$ & $\begin{array}{l}68.8 \\
53.2\end{array}$ & 1.48 & 0.224 \\
\hline $\begin{array}{l}\text { Monthly income (Naira) } \\
\leq 30,000 \text { (min. wage) } \\
>30,000 \text { and above }\end{array}$ & $\begin{array}{l}89 \\
49 \\
\end{array}$ & $\begin{array}{l}48.1 \\
57.4 \\
\end{array}$ & $\begin{array}{c}96 \\
115 \\
\end{array}$ & $\begin{array}{l}51.9 \\
42.6 \\
\end{array}$ & 0.86 & 0.353 \\
\hline $\begin{array}{c}\text { Knowledge of vaccine importance } \\
\text { Good } \\
\text { Fair } \\
\text { Poor }\end{array}$ & $\begin{array}{l}10 \\
44 \\
84 \\
\end{array}$ & $\begin{array}{l}29.4 \\
44.0 \\
50.6\end{array}$ & $\begin{array}{l}24 \\
56 \\
82 \\
\end{array}$ & $\begin{array}{l}70.6 \\
56.0 \\
49.4 \\
\end{array}$ & 16.40 & $<0.001^{*}$ \\
\hline $\begin{array}{c}\text { Self-risk perception of COVID } \\
\text { High risk } \\
\text { Some risk } \\
\text { No risk }\end{array}$ & $\begin{array}{l}22 \\
67 \\
49\end{array}$ & $\begin{array}{l}28.9 \\
46.5 \\
61.3\end{array}$ & $\begin{array}{l}54 \\
77 \\
31\end{array}$ & $\begin{array}{l}71.1 \\
53.5 \\
38.7\end{array}$ & 22.01 & $<0.001^{*}$ \\
\hline $\begin{array}{c}\text { Awareness of any COVID-19 } \\
\text { associated mortality } \\
\text { Yes } \\
\text { No } \\
\end{array}$ & $\begin{array}{l}39 \\
99 \\
\end{array}$ & $\begin{array}{l}34.2 \\
53.2 \\
\end{array}$ & $\begin{array}{l}75 \\
87\end{array}$ & $\begin{array}{l}65.8 \\
46.8 \\
\end{array}$ & 10.28 & $0.001^{*}$ \\
\hline $\begin{array}{c}\text { Previous history of vaccination for } \\
\text { respondent } \\
\text { Yes } \\
\text { No }\end{array}$ & $\begin{array}{c}122 \\
16\end{array}$ & $\begin{array}{l}44.0 \\
69.6\end{array}$ & $\begin{array}{c}155 \\
7\end{array}$ & $\begin{array}{l}56.0 \\
30.4\end{array}$ & 5.569 & $0.018^{*}$ \\
\hline $\begin{array}{l}\text { Child's previous history of } \\
\text { vaccination } \\
\text { Yes } \\
\text { No }\end{array}$ & $\begin{array}{l}71 \\
13\end{array}$ & $\begin{array}{l}42.0 \\
81.3\end{array}$ & $\begin{array}{c}98 \\
3\end{array}$ & $\begin{array}{l}58.0 \\
18.8\end{array}$ & 9.08 & $0.003^{*}$ \\
\hline
\end{tabular}

When multiple logistic regression was carried out, it was found that respondents who had no risk perception for COVID-19 had more than twice the odds of vaccine hesitancy compared to those who perceived some risk (AOR=2.4, 95\% $\mathrm{CI}=1.16-4.98$ ) while those with high risk perception had lower odds of vaccine hesitancy compared to those who perceived some risk (AOR=0.57, 95\% CI $=0.24-0.98)$. Respondents who had no previous history of vaccination also had over thrice the odds of vaccine hesitancy when compared to those who had previously been vaccinated $(\mathrm{AOR}=3.61,95 \%$ $\mathrm{CI}=1.00-13.02)$. (Table 5) 


\begin{tabular}{|c|c|c|c|}
\hline & $\begin{array}{c}\text { Adjusted Odds } \\
\text { Ratio }\end{array}$ & $\begin{array}{c}\text { 95\% Confidence } \\
\text { Interval }\end{array}$ & p-value \\
\hline $\begin{array}{c}\text { Level of education } \\
\text { Pre-secondary }\end{array}$ & 1 & & \\
Secondary and above & 0.67 & $0.33-1.38$ & 0.279 \\
\hline $\begin{array}{c}\text { Knowledge of vaccines } \\
\text { Good }\end{array}$ & 1 & & \\
Fair & 1.41 & $0.58-3.76$ & 0.410 \\
Poor & 1.78 & $0.80-2.75$ & 0.217 \\
\hline $\begin{array}{c}\text { Self-risk perception of COVID } \\
\text { High risk } \\
\text { No risk }\end{array}$ & 0.57 & $0.24-0.98$ & $0.042^{*}$ \\
Some risk & 2.40 & $1.16-4.98$ & $0.018^{*}$ \\
\hline $\begin{array}{c}\text { Awareness of any COVID-19 } \\
\text { associated mortality } \\
\text { Yes } \\
\text { No }\end{array}$ & 0.59 & $0.31-1.08$ & 0.086 \\
\hline $\begin{array}{c}\text { Previous history of vaccination for } \\
\text { respondent } \\
\text { Yes } \\
\text { No }\end{array}$ & 1 & & \\
\hline $\begin{array}{c}\text { Child's previous history of } \\
\text { vaccination }\end{array}$ & 1 & & \\
Yes & & & \\
No & 1 & & \\
\hline$\quad$ & 1.04 & $0.53-2.08$ & \\
\hline
\end{tabular}

Table 5: Predictors of Vaccine Hesitancy

*Significant

\section{Discussion}

This study showed that almost half of respondents were hesitant to COVID-19 vaccine. Studies conducted in different parts of the world have shown varying degrees of vaccine hesitancy, even among mothers that should be aware of the importance of vaccination especially for children [19,20]. A global survey of potential acceptance of COVID-19 vaccine found that acceptance rates ranged from about $55 \%$ to $90 \%$ in which up to $71.5 \%$ of participants were somewhat willing to accept the vaccine and $48.1 \%$ were willing to accept the vaccine based on their employer's recommendation to do so [18]. Some studies conducted in India and Pakistan showed that the prevalence of vaccine hesitancy among caregivers and parents of under-fives were 29\% [21] and 27.9\% [22], although the hesitancy was for the routine childhood vaccines. Compared to the findings in this study, lower prevalence of hesitancy to COVID-19 vaccine has been reported in Ireland and the United Kingdom with prevalence of 35\% and 31\% respectively [16]. In an American study, vaccine acceptance was found to be up to $69 \%$ [17]while it was $29.4 \%$ in a study conducted in Kuwait [22].Generally; the acceptance rate for COVID-19 vaccine has been demonstrated to be over $70 \%$ globally with the level of acceptance lower in Africa, Middle East, some European countries and Russia [23].The low levels of COVID-19 vaccine hesitancy in some countries may be due to the high level of awareness about the pandemic and trust in government measures in combating it.

Knowledge of the importance of vaccines is necessary in making decisions concerning acceptance of vaccination service. In this study, few respondents demonstrated good knowledge of vaccine importance which is similar to the observations from studies conducted in Israel [24] and Rome [19] where knowledge levels were generally low. Studies conducted among health care workers generally showed better knowledge levels [24, 25].

Majority of the respondents in this study mentioned side effect as reason for their hesitancy to COVID-19 vaccination, which is also a major reason that has been mentioned in other studies[25, 26, 27]. Other reasons mentioned by respondents in this study and in many other studies [24, 25, 27, 28], have demonstrated that respondents are concerned about the efficacy of the vaccines, the policies/politics guiding vaccination and rumours concerning microchips that might be inserted into the vaccines. Other reports have shown that many Africans at one point or the other since the outbreak of the pandemic, have displayed lack of confidence and trust in the government and its policies with regards to COVID-19 control. Many people believe that the policies that were formulated did not apply to the elites but were made to target the poor masses such as laxity in implementing boarder closure at the beginning of the pandemic. This also may contribute to their lack of trust in any COVID-19 related vaccination programme brought in by the Government[13]. Differences in educational level, type of profession like being a health worker, access to information and other sociocultural factors may also explain the barrage of reasons why individuals have some form of hesitancy to COVID-19 vaccine. Just little above a quarter of the respondents in this study perceived to be at high risk of COVID-19 infection, although the reason for this feeling was not probed further. This perception may be related to the occupation of the respondents, most especially being a health worker which was less than $10 \%$ in this study. A previous study conducted in the Plateau state observed that risk-perception for COVID-19 was significantly higher among health workers than non-health workers [29].The implication of this is that, as health workers remain the most trusted source of information on vaccination, there 
is a risk that the hesitant ones might discourage their patients or even the general population from accepting the vaccines [25]. Although this study was conducted among members of the general community as a focus, it would be good to also conduct a study that will focus only on health care professionals in this setting so as to be able to provide a proper link between these groups of individuals.

Few respondents $(<10 \%)$ in this study reported never being vaccinated and few had not vaccinated their children in the past. These had higher rates of vaccine hesitancy compared to those who had past histories of vaccination, even though the reasons for not being vaccinated were not elicited. Previous studies in many parts of the world including Nigeria, New York (USA), France and Greece showed that respondents who had negative experiences after vaccination ended up not getting subsequently vaccinated or allowing their children to be vaccinated $[20,25,30]$.

Respondents who had low self-perception of risk for COVID-19 and no previous history of vaccination had higher odds of vaccine hesitancy in this study. Self-risk perception and vaccination history were also found to be significant predictors of vaccine hesitancy in a study conducted in Israel, although vaccination history was specific for influenza vaccine [24]. Respondents' level of education, knowledge of vaccine importance, risk perception to COVID-19, awareness of any COVID19 associated mortality and child's history of being ever vaccinated were associated with COVID-19 vaccination hesitancy but not found to be significant predictors. Other studies, though using different designs and methodology found age, risk perception and knowing someone (relative) with COVID-19 as determinants of vaccine hesitancy [31, 32].

\section{Conclusion}

Almost half of respondents in this study were found to be hesitant to COVID-19 vaccine with the fear of side effect stated as the major reason for this hesitancy. Furthermore, self-risk perception of COVID-19 and previous history of getting vaccinated against any disease was found to be significant predictors of vaccine hesitancy. It is therefore, essential for the government and the health system to educate the entire population and build up their confidence in the efficacy and safety of these vaccines that have proven to be highly efficacious and necessary in combating the menace.

Limitation: This study was carried out only among literate residents with access to mobile phones and internet thus, findings may not be entirely representative of the general population.

Financial support and sponsorship: This study was entirely funded by the authors.

Conflicts of interest: There are no conflicts of interest.

Authors contributions: C.O.O, O.E, GD, MB, DG all participated in the literature review; concept and design of the study; data collection; analysis and interpretation of data; drafting and revising the manuscript; and final approval prior to submission for publication.

\section{References}

i. Dubé E, Laberge C, Guay M, Bramadat P, Roy R, Bettinger J. Vaccine hesitancy: an overview. Hum Vaccin Immunother. 2013;9(8):1763-73. PubMed PMID: 23584253. Epub 04/12. eng.

ii. WHO. COVAX: Working for global equitable access to COVID-19 vaccines. 2021 [cited 202104 Feb]. Available from: https://www.who.int/initiatives/act-accelerator/covax.

iii. Ogundele 0 , Ogundele T, Beloved 0 . Vaccine hesitancy in Nigeria: Contributing factors - way forward. Niger J Gen Pract. 2020;18(1):1.

iv. Lane S, MacDonald NE, Marti M, Dumolard L. Vaccine hesitancy around the globe: Analysis of three years of WHO/UNICEF Joint Reporting Form data-2015-2017. Vaccine. 2018;36(26):3861-7.

v. MacDonald NE, Eskola J, Liang X, Chaudhuri M, Dube E, Gellin B, et al. Vaccine hesitancy: Definition, scope and determinants. Vaccine. 2015;33(34):4161-4.

vi. Worldometer. COVID-19 CORONAVIRUS PANDEMIC. 2021 [cited 202116 March]. Available from: https://www.worldometers.info/coronavirus/.

vii. WHO. Coronavirus disease (COVID-19): Vaccines. 2020 [cited 202101 Feb]. Available from: https://www.who.int/news-room/q-a-detail/coronavirus-disease-(covid-19)vaccines?adgroupsurvey $=\{$ adgroupsurvey $\} \&$ gclid=CjwKCAiAsOmABhAwEiwAEBR0Znt0j1LIi095R1zF5HCIVSQ2uWJfYmr5srRJF0T5TTbeumh9aHTvBoCg8MQAvD_BwE.

viii. WHO. Ten threats to global health in 20192021 [cited 202112 Jan]. Available from: https://www.who.int/news-room/spotlight/ten-threats-to-global-health-in-2019.

ix. U.S Food and Drug Administration. FDA Issues Emergency Use Authorization for Third COVID-19 Vaccine. 2021 [cited 2021 March 17]. Available from: https://www.fda.gov/news-events/press-announcements/fdaissues-emergency-use-authorization-third-covid-19-vaccine.

x. CDC. COVID-19 Vaccine Emergency Use Authorization (EUA) Fact Sheets for Recipients and Caregivers. 2021 [cited 2021 March 17]. Available from: https://www.cdc.gov/vaccines/covid-19/eua/index.html.

xi. WHO. COVID 19 Vaccine 2021 [cited 202102 Feb]. Available from: https://www.who.int/emergencies/diseases/novel-coronavirus-2019/covid-19-vaccines.

xii. Cooper S, Betsch C, Sambala EZ, McHiza N, Wiysonge CS. Vaccine hesitancy - a potential threat to the achievements of vaccination programmes in Africa. Hum Vaccin Immunother. 2018;14(10):2355-7. PubMed PMID: 29617173. Epub 05/22. eng.

xiii. Afolabi AA, Ilesanmi OS. Dealing with vaccine hesitancy in Africa: the prospective COVID-19 vaccine context. Pan African Medical Journal. 2021;38(3):1-7.

xiv. Schaffer DeRoo S, Pudalov NJ, Fu LY. Planning for a COVID-19 Vaccination Program. JAMA. 2020;323(24):2458-9. 
xv. Evstatieva M. Elements Of A Coronavirus Conspiracy: 5G, Vaccinations, Bill Gates : NPR [Internet]. 2020 [cited 2020 Sep 23]. Available from: https://www.npr.org

xvi. NCDC. COVID 19 Nigeria. 2021 [cited 202103 Feb]. Available from: https://covid19.ncdc.gov.ng/.

xvii. Nigeria Galleria. Plateau State of Nigeria :: Nigeria Information \&amp; Guide [Internet]. Galleria Media limited. 2017 [cited 2020 Jul 15]. Available from: https://www.nigeriagalleria.com

xviii. Lazarus JV, Ratzan SC, Palayew A, Gostin LO, Larson HJ, Rabin K, et al. A global survey of potential acceptance of a COVID-19 vaccine. Nature Medicine. 2021 2021/02/01;27(2):225-8.

xix. Dubé È, Farrands A, Lemaitre T, Boulianne N, Sauvageau C, Boucher FD, et al. Overview of knowledge, attitudes, beliefs, vaccine hesitancy and vaccine acceptance among mothers of infants in Quebec, Canada. Hum Vaccin Immunother. 2019;15(1):113-20. PubMed PMID: 30095325. Pubmed Central PMCID: PMC6363056. Epub 2018/08/11. eng.

xx. Cunningham RM, Minard CG, Guffey D, Swaim LS, Opel DJ, Boom JA. Prevalence of Vaccine Hesitancy Among Expectant Mothers in Houston, Texas. Academic pediatrics. 2018 Mar;18(2):154-60. PubMed PMID: 28826731. Epub 2017/08/23. eng.

xxi. Sikder R, Mukherjee D, Pattanayak U, Majumdar KK, Kundu SS, Dey R, et al. Prevalence of vaccine hesitancy and its associated factors in an urban area of West Bengal, India. International Journal Of Community Medicine And Public Health. 2020 2020-08-28;7(9):3443-9. Epub 2020-08-28.

xxii. Khattak FA, Rehman K, Shahzad M, Arif M, UllahN, Kibria Z, et al. Prevalence of Parental refusal rate and its associated factors in routine immunization by using WHO Vaccine Hesitancy tool: A Cross sectional study at district Bannu, KP, Pakistan. International Journal of Infectious Diseases. 2021;104:117-24.

xxiii. Sallam M. COVID-19 vaccine hesitancy worldwide: a systematic review of vaccine acceptance rates. medRxiv. 2021:2020.12.28.20248950.

xxiv. Dror AA, Eisenbach N, Taiber S, Morozov NG, Mizrachi M, Zigron A, Srouji S, Sela E. Vaccine hesitancy: the next challenge in the fight against COVID-19. Eur J Epidemiol. 2020; 35(8): 775-779. doi: 10.1007/s10654-02000671-y. Epub 2020 Aug 12. PMID: 32785815.

xxv. Mizuta AH, Succi GM, Montalli VAM, Succi RCM. PERCEPTIONS ON THE IMPORTANCE OF VACCINATION AND VACCINE REFUSAL IN A MEDICAL SCHOOL. Revista paulista de pediatria : orgao oficial da Sociedade de Pediatria de Sao Paulo. 2019 Jan-Mar;37(1):34-40. PubMed PMID: 30110112.

xxvi. Facciola A, Visalli G, Orlando A, Bertuccio MP, Spataro P, Squeri R, et al. Vaccine hesitancy: An overview on parents' opinions about vaccination and possible reasons of vaccine refusal. J Public health Res. 2019;8(1):138.

xxvii. Cherian V, Saini NK, Sharma AK, Philip J. Prevalence and predictors of vaccine hesitancy in an urbanized agglomeration of New Delhi, India. Journal of Public Health. 2021:https://doi.org/10.1093/pubmed/fdab007.

xxviii. Suwantika AA, Boersma C, Postma MJ. The potential impact of COVID-19 pandemic on the immunization performance in Indonesia. Expert Review of Vaccines. Taylor and Francis Ltd; 2020.

xxix. Okoh EO, Maimagani CI, Adamu U, Okoh AF, Chirdan O. Knowledge of covid-19, risk perception and prevention practices among residents of Plateau State, Nigeria. European Journal of Pharmaceutical and Medical Research. 2020;7(9):15-21.

xxx. Sallam M, Dababseh D, Eid H, Al-Mahzoum K, Al-Haidar A, Taim D, et al. High Rates of COVID-19 Vaccine Hesitancy and Its Association with Conspiracy Beliefs: A Study in Jordan and Kuwait among Other Arab Countries. Vaccines. 2021 Jan 12;9(1):42. doi: 10.3390/vaccines9010042.

xxxi. Harrison EA, Wu JW. Vaccine confidence in the time of COVID-19. Eur J Epidemiol. 123AD;1:3.

xxxii. Cornwall W. Just 50\% of Americans plan to get a COVID-19 vaccine. Here's how to win over the rest [Internet]. Science. 2020 [cited 2020 Aug 18]. Available from: https://www.sciencemag.org 